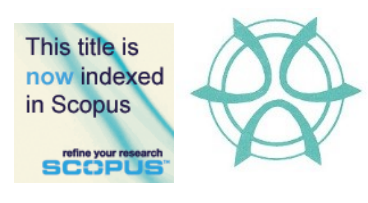

PLANNING MALAYSIA:

Journal of the Malaysian Institute of Planners

VOLUME 18 ISSUE 2 (2020), Page 243 - 254

\title{
THE DERIVATION OF URBAN DESIGN PRINCIPLES IN MALAY-ISLAMIC TOWN OF KUALA TERENGGANU
}

\author{
Nurul Syala Abdul Latip ${ }^{1}$, Nor Zalina Harun², Alias Abdullah ${ }^{3}$, Mansor \\ Ibrahim $^{4}$
}

\begin{abstract}
Islam took root in the Malay Sultanate kingdom when trade flourished through the Straits of Malacca and the South China Sea. Islamic teaching was accepted by the locals and Islam became the country's official religion. Islam has been assimilated in the way of life of the Malays, including the physical built environment of its cities. However, after colonisation, many of the Malay town structure had changed tremendously following the western planning. Remnants of the Malay-Islamic state footprint can still be traced in the town of Kuala Terengganu. This paper aims to establish the urban design principles influenced by the Islamic values which are embedded in and characterised in Kuala Terengganu. Employing a qualitative method, secondary and primary data (observation using photography) were collected. Content analysis were conducted on the observation data, archival documents, historical literatures and morphological study on Kuala Terengganu Town and triangulated with the literature on principles gathered from the characteristic of Islamic cities. The findings revealed that Kuala Terengganu has similar characteristics to other Islamic cities however it is translated in the local context. The comparison revealed fifteen Urban Design principles related to the Malay-Islamic Town of Kuala Terengganu that are well-assimilated and embedded within the local culture, geography and climate for the reference of future city planners.
\end{abstract}

Keywords: Urban design principles, Malay-Islamic town, Kuala Terengganu

\footnotetext{
${ }^{1}$ Senior Lecturer at Universiti Sains Islam Malaysia. Email: nurulsyala@usim.edu.m
} 
Nurul Syala Abdul Latip \& Nor Zalina Harun, Alias Abdullah, Mansor Ibrahim

Derivation of Urban Design Principles in Malay-Islamic Town of Kuala Terengganu

\section{INTRODUCTION}

Islam reached the Nusantara region as early as $9^{\text {th }}$ century, as determined by the traces of artefacts found in Tanah Melayu. The trade route was instrumental in the spreading of Islam to local lands. Across water, the route spanned from Jeddah through the Red Sea to Aden, south of the Arab peninsular than to Gujerat (India) directly to Nusantara. Across land, it started in Syria or Iraq to Khurasan, north of Parsi to Afghanistan, then to China and later to Nusantara (Muhammad Hasan al-Aydrus, 1996). It brought Muslim traders from the Middle East and Muslim Chinese traders to Nusantara, including port cities such as Melaka, Aceh and in the east, port cities such as Kuala Terengganu. Islam took root and assimilated in the existing local culture. There was clear evidence that Islamic Law was legitimized as the official law in Terengganu in the 1300s based on the evidence in the Inscription Stone found dated $702 \mathrm{H}(1303 \mathrm{M})$. The aim of this paper is to study how Islam has influenced urban design principles in the Malay town of Kuala Terengganu.

\section{BACKGROUND}

\section{The arrival of Islam and its practice}

Islam is a way of life. The direct translation on the meaning of Islam is 'peace'. Islam is actually a peaceful religion for a person/ community/ environment when the system guided by Allah through the Quran and conveyed by the Prophet Muhammad S.A.W is implemented, practiced and focused towards submission to Allah in the development of human kind. This includes development of cities as mentioned in Surah Al-Naml 27:91-92:

[Say, O Muhammad], "I have only been commanded to worship the Lord of this city, who made it sacred and to whom [belongs] all things. And I am commanded to be of the Muslims [those who submit to Allah]. And to recite the Qur'an." And whoever is guided is only guided for [the benefit of] himself; and whoever strays - say, "I am only [one] of the warners."

In the Quran, Allah mentioned fourteen (14) times about cities, their features and populations. Based on the theory by Besim Hakim (1986) of Arab-Islamic cities (Figure 1), there were two type of cities established. One type includes those built with Shariah, and the other was assimilated into Shariah, moulded into the existing physical structure (Figure 1). The latter was particularly so when Islam arrived and took root in established cities. Islamic culture 'peacefully' developed, assimilated and embraced the regional cultural characteristics which did not contradict Shariah. This is highlighted in verse 5, Surah Al-Maidah, as Allah allows people to consume or use all good things, and accepts practices of good behaviour and implementation. 
PLANNING MALAYSIA

Journal of the Malaysia Institute of Planners (2020)

Surah Al-Maidah 5 verses 5:

"This day [all] good foods have been made lawful, and the food of those who were given the Scripture is lawful for you and your food is lawful for them...."

Based on Figure 1, the physical changes that happen in a city with the macro setting of the urban area are decided by the rulers, while the micro setting of the dwellings and neighbourhoods are determined by citizens. These decisions were made very much depending on the site, environmental and geographical condition of the place so and does not contradict with the natural law. The importance of responding to the natural law is mentioned by Allah in Surah AsSyuara 26:7-9.

'Did they not look at the earth - how much We have produced therein from every noble kind? 'Verily, in this is a Sign: but most of them do not believe'. And verily, thy Lord is He, the Exalted in Might, Most Merciful.

These verses have guided decision makers to look at the earth, study the geographical and climate conditions of a place before decisions are made to fulfil the needs of the people. Based on Imam Abu Hanifa (80 A.H-150 A.H) and Imam Malik (93 A.H-179 A.H), the founder of a predominant school of law, the nucleus of a medina/city should be in the interconnection of these three aspects: governance ( $k a d i)$, the masjid, and the market (suq) market and its surroundings (Figure 2). The interrelationships between these components make up a strong Islamic city (Shojaee, 2015). A great sample of the nucleus is the development of the first Islamic City, Madinah, by Prophet Muhammad S.A.W. All the three components were very closely related physically through linkages. The governor, the Prophet S.A.W himself, had his house next to the Masjid Nabawi, which was then the centre of learning, recreation, community and health. Surrounding the mosques were the $s u q$ and the residences. Their close proximity allows the people to contact the leader/ governor for any problems. The linkages were also wellshaded and well-ventilated with clear air space in response to the climate. through the enclosures created by the proximity of the buildings and organic urban patterns. Furthermore, within the residences were the district rules, which were comparatively different to those of contemporary cities. 
Nurul Syala Abdul Latip \& Nor Zalina Harun, Alias Abdullah, Mansor Ibrahim

Derivation of Urban Design Principles in Malay-Islamic Town of Kuala Terengganu

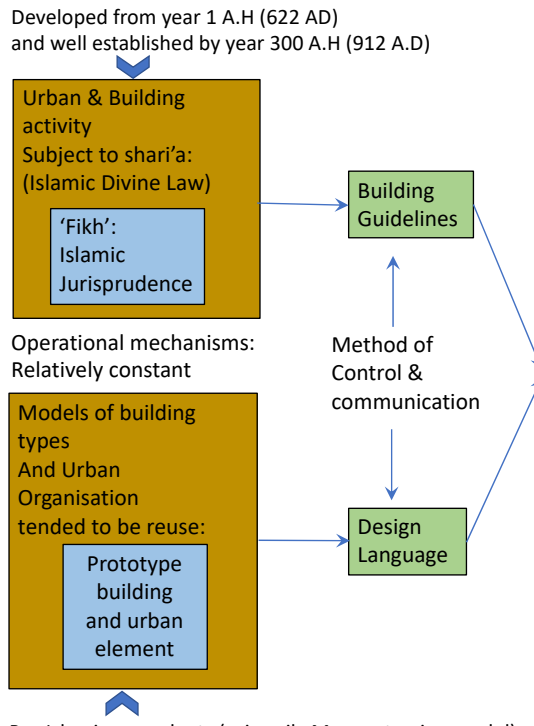

Pre-Islamic precedents (primarily Mesopotamian model) Was spread with Islamic expansion and evolved within various regions of Islamic world

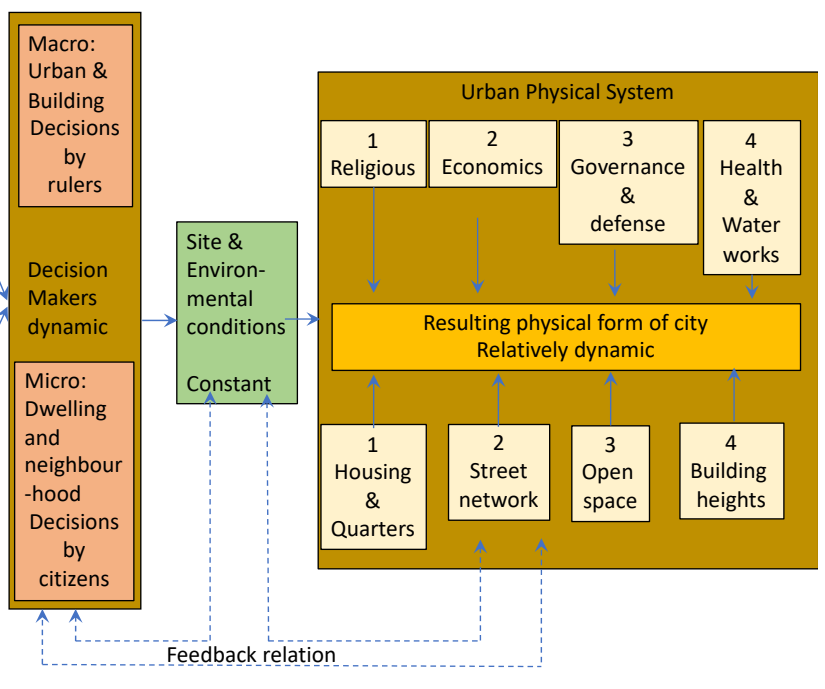

Figure 1. Conceptual Model of Selected Factors that shaped the traditional Arab-Islamic City (Source: Besim Hakim, 1986: Redrawn by Author)

\section{Nucleus of Medina City}

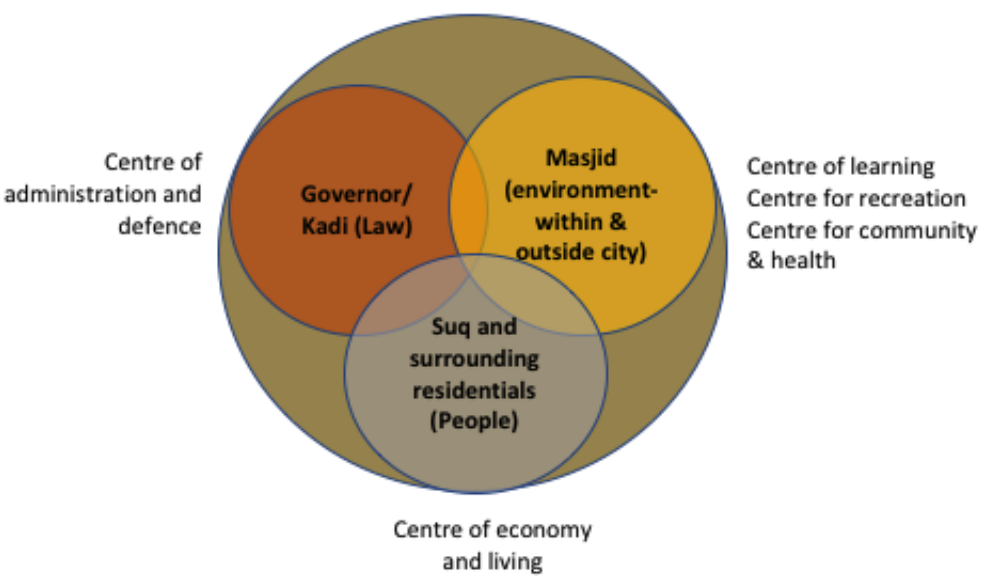

Figure 2. Nucleus of a Medina/ City by Imam Abu Hanifa and Imam Malik (Source: Besim Hakim, 1986. Illustrated by Author)

In the layout of a medina, the proximity of different income groups within the same cluster encourages interdependence and mutual respect to neighbours regardless of their income or status (Besim Hakim, 1986). This is in contrast to 
contemporary cities, which encourage segregation based on plot size, which invariably means economic and social segregation. The medina cities were also built based on Shariah, and the neighbourhood building guidelines prioritize the aspect of privacy and safety. Free water supply is also a crucial aspect in a medina. The evidence is clear based on the history of Sayyidina Uthman, the Prophet's companion, whom bought the water well in Medina and later open free for all communities because water is the right given by Allah to human being without charge. Finally, in Madinah, the Islamic governance embraced the different cultural and religion and thorough consideration was given in the Madinah Constitution for the peacefulness of the city. Each culture has their own area to freely conduct their practices without conflict with others. The spaces to meet and mingle are in the common areas such as the street, the market and open spaces. Based on the discussion above, it can be concluded on the basic principles implemented in Arab-Islamic cities are as shown in Table 1. Based on integrative theory of urban design (Sternberg, 2007) and the characteristics identified in the Arab-Islamic Cities, this paper will evaluate whether the same principles were applied in the context of the Malay-Islamic cities of Kuala Terengganu.

Table 1. Integrative Urban Design Theory and characteristic of Arab-Islamic Cities.

\begin{tabular}{|c|c|c|c|}
\hline \multicolumn{2}{|c|}{$\begin{array}{l}\text { Integrative Urban } \\
\text { Design Theory }\end{array}$} & \multirow{3}{*}{$\begin{array}{l}\begin{array}{l}\text { Characteristics of } \\
\text { Arab-Islamic Cities }\end{array} \\
\text { Based on the Islamic } \\
\text { Jurisprudence (Law) }\end{array}$} & \multirow{3}{*}{$\begin{array}{l}\text { Descriptions } \\
\text { Response to the Natural } \\
\text { Law, building principles \& } \\
\text { respect the culture of the } \\
\text { place which is according to } \\
\text { the guidance of the Quran }\end{array}$} \\
\hline Physical & Good & & \\
\hline Dimension & Form & & \\
\hline & & \multirow{2}{*}{$\begin{array}{l}\text { Pedestrian-scaled } \\
\text { environment } \\
\text { (Religious and Cultural } \\
\text { Beliefs) }\end{array}$} & $\begin{array}{l}\text { Humane and comfortable to } \\
\text { pedestrian - no cars }\end{array}$ \\
\hline & & & $\begin{array}{l}\text { Separating public and } \\
\text { private domain - land use } \\
\text { emphasizes the separation of } \\
\text { male and female uses }\end{array}$ \\
\hline & & $\begin{array}{l}\text { Same form \& pattern for } \\
\text { housing } \\
\text { (Religious and Cultural } \\
\text { Beliefs) }\end{array}$ & $\begin{array}{l}\text { Only the size of living area, } \\
\text { type of building materials } \\
\text { and sophistication of applied } \\
\text { decoration distinguish one } \\
\text { from another }\end{array}$ \\
\hline & Legibility & $\begin{array}{l}\text { Legible to the locals but } \\
\text { not legible for first } \\
\text { timers/ outsiders }\end{array}$ & $\begin{array}{l}\text { Well link to all three } \\
\text { components (governance, } \\
\text { masjid, souq \& residential) } \\
\text { within a } 400 \text { m radius. }\end{array}$ \\
\hline
\end{tabular}


Nurul Syala Abdul Latip \& Nor Zalina Harun, Alias Abdullah, Mansor Ibrahim

Derivation of Urban Design Principles in Malay-Islamic Town of Kuala Terengganu

\begin{tabular}{|c|c|c|c|}
\hline & & \multirow{2}{*}{$\begin{array}{l}\text { The locals knew their } \\
\text { neighbours well but it is } \\
\text { not legible for first } \\
\text { timers/ outsiders for } \\
\text { safety purposes so that } \\
\text { the neighbourhood knew } \\
\text { that an outsider has } \\
\text { arrived. } \\
\text { Furthermore, it is legible } \\
\text { with high accessibility } \\
\text { and permeability. }\end{array}$} & \multirow[t]{2}{*}{$\begin{array}{l}\text { Accessible and permeable } \\
\text { within neighbourhood and to } \\
\text { the three main components } \\
\text { of the leader's house - the } \\
\text { mosque -market \& } \\
\text { surrounding residentials }\end{array}$} \\
\hline & & & \\
\hline \multirow[t]{7}{*}{$\begin{array}{l}\text { Functional } \\
\text { Dimension }\end{array}$} & \multirow[t]{2}{*}{ Vitality } & $\begin{array}{l}\text { Common public areas - } \\
\text { Robust in function }\end{array}$ & $\begin{array}{l}\text { Masjid, Market and Open } \\
\text { spaces (e.g. streets are also } \\
\text { use for children to play) }\end{array}$ \\
\hline & & $\begin{array}{l}\text { Living and working area } \\
\text { is in close proximity }\end{array}$ & low carbon foot print \\
\hline & \multirow[t]{2}{*}{ Comfort } & $\begin{array}{l}\text { Climatic responsive, } \\
\text { safety and privacy }\end{array}$ & $\begin{array}{l}\text { Well shaded and ventilated } \\
\text { public spaces and considered } \\
\text { the safety and privacy aspect }\end{array}$ \\
\hline & & Water for all & God Gift \\
\hline & \multirow[t]{3}{*}{ Meaning } & $\begin{array}{l}\text { Cluster according to } \\
\text { kinship }\end{array}$ & $\begin{array}{l}\text { Culturally responsive which } \\
\text { allows different race and } \\
\text { religion to practice their } \\
\text { culture in their own vicinity }\end{array}$ \\
\hline & & & $\begin{array}{l}\text { Closely link neighbourhood } \\
\text { - will know if strangers are } \\
\text { in the area }\end{array}$ \\
\hline & & $\begin{array}{l}\text { No segregation between } \\
\text { housing area for rich } \\
\text { and poor }\end{array}$ & $\begin{array}{l}\text { Different status of people } \\
\text { living next to each other and } \\
\text { within the same housing } \\
\text { cluster }\end{array}$ \\
\hline
\end{tabular}

\section{METHODOLOGY}

The research approach of a case study of Malay-Islamic Town of Kuala Terengganu. Kuala Terengganu was chosen because the city provides clear evidence of the implementation of Islamic laws, earlier than Malacca, and it was the last state in the country to accept a British advisor (Haji Buyong Adil, 1982). The town planning was established by the Malay Sultanate. However, it is believed that Islam has arrived earlier than the recorded date, because the Inscription Stone portrayed a very strong root of the Malays Muslim due to the establishment of jawi writing. The content of the Inscription stone bears an 
established Language, Writing, Systemised Social Structure, Islamic Law, Economics, Astronomical Knowledge, Mathematics and others, and shows that Malay Muslim has established a civilisation and cities (Abdullah Zakaria Ghazali, 1984). Furthermore, the estimated population of Kuala Terengganu in 1905 was 25,000 people with the largest urban Malay population in Malay Peninsula. The population number was the largest in the Unfederated Malay state, five times larger than Kuala Lumpur. The town flourished economically the highest compared to any other state in Malaya during that time. It practices barter trading of its own resources such as brass, batik production with other parts of the world (Khoo Kay Kim, 1974). Most of the original urban footprint remained until today. The study employs qualitative technique using morphological analysis and content analysis of archival maps and literatures. Morphological analysis is used to understand the physical development of an area since its early establishment to the current situation. Observations using photography were used to document the existing physical development. Triangulation data from these techniques allowed the evolution of the actual urban space, its building forms and the city's core principles.

\section{FINDINGS AND DISCUSSION}

Through the morphological study, the Urban Design Principles in Kuala Terengganu are identified based on the description of the characteristic of town and its components as shown in Table 2 . The city shares distinct similarities to the principles available in Arab-Islamic cities but was built within the needs of the Kuala Terengganu local context. The implementation of these principles in each settlement can be seen clearly in Kuala Terengganu. The houses were built according to the Islamic Jurisprudence, taking into consideration the privacy and cleanliness in its space planning and architecture based on the teaching of the Quran. Their design respects the natural law with the use of renewable material and responsive to the local climate and geographical context. The height of the buildings was comfortably humane and all streets were designed for pedestrian only - wonderfully achieved before motor vehicles were introduced to Terengganu. The form of the buildings had a strong identity, with the pointed roof and the janda berhias wall, which are identifiable as forming the character of the traditional house of Terengganu.

Table 2. Urban design principles in Kuala Terengganu Malay-Islamic town

\begin{tabular}{llll}
\hline BUILT BY THE GOVERNMENT & & \\
\hline Integrative & Urban Design & Description of Malay-Islamic & Components \\
Theory of & Principles in the & Settlement Characteristic & \\
Urban Design & Malay-Islamic & \\
& Settlement & \\
\hline Functional Dimension & \\
\hline
\end{tabular}


Nurul Syala Abdul Latip \& Nor Zalina Harun, Alias Abdullah, Mansor Ibrahim Derivation of Urban Design Principles in Malay-Islamic Town of Kuala Terengganu

\begin{tabular}{|c|c|c|c|}
\hline \multirow[t]{4}{*}{ Comfort } & $\begin{array}{l}\text { Complete } \\
\text { neighbourhood }\end{array}$ & $\begin{array}{l}\text { People can live, work and receive } \\
\text { basic needs (shelter, food and } \\
\text { clothing) }\end{array}$ & $\begin{array}{l}\text { City has all basic needs } \\
\text { (e.g market/ shops, } \\
\text { masjid, governance, } \\
\text { houses, rightful location } \\
\text { of community well) }\end{array}$ \\
\hline & \multirow{3}{*}{ Health \& Safety } & \multirow[b]{2}{*}{ Safety and defence } & Governance (e.g Palace) \\
\hline & & & $\begin{array}{l}\text { Defence (e.g Fort/ watch } \\
\text { tower) }\end{array}$ \\
\hline & & Source of clean water & Community well \\
\hline \multirow[t]{3}{*}{ Vitality } & Integration & Life Long learning & $\begin{array}{l}\text { Masjid) / Surau/ } \\
\text { Madrasah (Pondok) }\end{array}$ \\
\hline & \multirow[t]{2}{*}{ Conviviality } & \multirow{2}{*}{$\begin{array}{l}\text { Mix of different culture at } \\
\text { common spaces }\end{array}$} & Shops \& Market \\
\hline & & & Open Space (Padang) \\
\hline \multirow[t]{2}{*}{ Meaning } & \multirow{2}{*}{$\begin{array}{l}\text { Heritage } \\
\text { Conservation }\end{array}$} & \multirow[t]{2}{*}{ Preserve architecture and culture } & Traditional Architecture \\
\hline & & & Traditional Culture \\
\hline \multicolumn{4}{|c|}{ Physical Dimension } \\
\hline \multirow[t]{6}{*}{ Good Form } & \multirow[t]{2}{*}{ Blue Green City } & $\begin{array}{l}\text { Response to the river as the } \\
\text { source of water and main } \\
\text { transportation mode }\end{array}$ & $\begin{array}{l}\text { Palace / Government } \\
\text { buildings }\end{array}$ \\
\hline & & $\begin{array}{l}\text { Integrated with greens around the } \\
\text { city }\end{array}$ & $\begin{array}{l}\text { Trees planted around the } \\
\text { cities }\end{array}$ \\
\hline & Sustainable design & $\begin{array}{l}\text { Uses green technology (e.g } \\
\text { rainwater harvesting) }\end{array}$ & Government Building \\
\hline & \multirow[t]{2}{*}{ Efficiency } & $\begin{array}{l}\text { Energy \& resource efficient e.g } \\
\text { Well shaded and naturally } \\
\text { ventilated }\end{array}$ & Government Building \\
\hline & & Well shaded & Streets \\
\hline & Transition design & $\begin{array}{l}\text { Growth according to the needs of } \\
\text { people }\end{array}$ & overall city development \\
\hline \multirow[t]{5}{*}{ Linkages } & \multirow[t]{2}{*}{ Human Scale } & \multirow{2}{*}{$\begin{array}{l}\text { Streets and height of building } \\
\text { along the streets is pedestrian } \\
\text { scaled }\end{array}$} & Government Building \\
\hline & & & Streets \\
\hline & Ease of Movement & Permeable & Streets \\
\hline & Conviviality & $\begin{array}{l}\text { Provision of three main } \\
\text { components: Masjid, the palace } \\
\text { and market/ shops within } 400 \mathrm{~m} \\
\text { radius }\end{array}$ & Public building/ space \\
\hline & Public Space & Place for public gathering & Medan/ Padang \\
\hline
\end{tabular}

\begin{tabular}{lll}
\hline BUILT BY THE CITIZEN & & \\
\hline Functional Dimension & & \\
\hline Comfort & Many close distance work and & house with working space \\
& $\begin{array}{l}\text { living. Agriculture field or jetty } \\
\text { for fishing are within walking } \\
\text { distance }\end{array}$ \\
\hline
\end{tabular}


PLANNING MALAYSIA

Journal of the Malaysia Institute of Planners (2020)

\begin{tabular}{|c|c|c|c|}
\hline & $\begin{array}{l}\text { Complete } \\
\text { Neighbourhood }\end{array}$ & $\begin{array}{l}\text { People can live, work and receive } \\
\text { basic needs }\end{array}$ & $\begin{array}{l}\text { Neighbourhood has all } \\
\text { basic needs (e.g shops, } \\
\text { surau, leader, houses, } \\
\text { rightful location of } \\
\text { community/ individual } \\
\text { well }\end{array}$ \\
\hline & Health and safety & Clean water for all & Well at house \\
\hline Vitality & People's first & $\begin{array}{l}\text { No segregation between rich and } \\
\text { poor }\end{array}$ & No zoning of houses \\
\hline \multirow[t]{5}{*}{ Meaning } & Conviviality & $\begin{array}{l}\text { Neighbourhood clustered } \\
\text { according to kinship }\end{array}$ & arrangement of houses \\
\hline & Quality of life & $\begin{array}{l}\text { Strong neighbourhood and help } \\
\text { each other (gotong royong) }\end{array}$ & people's activity \\
\hline & Heritage & \multirow[t]{2}{*}{ Preserve architecture and culture } & Traditional Architecture \\
\hline & Conservation & & Traditional Culture \\
\hline & Public space & neighbourhood gathering & Laman \\
\hline \multicolumn{4}{|c|}{ Physical Dimension } \\
\hline \multirow[t]{12}{*}{ Good Form } & $\begin{array}{l}\text { Blue Green } \\
\text { Neighbourhood }\end{array}$ & $\begin{array}{l}\text { Response to the river as the } \\
\text { source of water and main } \\
\text { transportation (street) }\end{array}$ & Houses \\
\hline & Sustainable design & $\begin{array}{l}\text { Design response to climate and } \\
\text { local resources }\end{array}$ & houses/ public building \\
\hline & Privacy & $\begin{array}{l}\text { Emphasize on the aspect of } \\
\text { privacy (form and spatial layout) }\end{array}$ & Houses \\
\hline & Efficiency & Well shaded and ventilated & houses/ public building \\
\hline & $\begin{array}{l}\text { Neighbourhood } \\
\text { Character }\end{array}$ & $\begin{array}{l}\text { Similar form and pattern for } \\
\text { housing (But the size of spaces, } \\
\text { type of building materials and } \\
\text { sophistication of decoration } \\
\text { applied distinguish one from } \\
\text { another) }\end{array}$ & houses \\
\hline & Human scale & $\begin{array}{l}\text { Pedestrian Scaled Environment. } \\
\text { Low rise buildings ( } 2-4 \text { stories) }\end{array}$ & houses/ public building \\
\hline & Transition design & $\begin{array}{l}\text { grow according to the needs of } \\
\text { people }\end{array}$ & $\begin{array}{l}\text { overall neighbourhood } \\
\text { development }\end{array}$ \\
\hline & \multirow[t]{3}{*}{ Ease of movement } & Well shaded & Street \\
\hline & & $\begin{array}{l}\text { High permeability between } \\
\text { buildings }\end{array}$ & Street \\
\hline & & $\begin{array}{l}\text { Accessible (within } \\
\text { neighbourhood and to all three } \\
\text { main components surau, the } \\
\text { leaders house and shops) }\end{array}$ & Street \\
\hline & People's first & $\begin{array}{l}\text { Pedestrian oriented (built for } \\
\text { people not for cars) }\end{array}$ & Street \\
\hline & Safety & $\begin{array}{l}\text { Eyes on the street (With the long } \\
\text { windows/ lattice/ carvings on the } \\
\text { façade create a safe environment } \\
\text { for people on the streets.) }\end{array}$ & Houses \\
\hline
\end{tabular}


Nurul Syala Abdul Latip \& Nor Zalina Harun, Alias Abdullah, Mansor Ibrahim

Derivation of Urban Design Principles in Malay-Islamic Town of Kuala Terengganu

\begin{tabular}{lll}
\hline Linkages & $\begin{array}{l}\text { Legible to the locals (It is legible } \\
\text { to the locals because they knew } \\
\text { their neighbours well but it is not } \\
\text { legible for first timers for safety) }\end{array}$ \\
\hline Public space & neighbourhood gathering & Laman
\end{tabular}

This approach allows the rich and poor to leave next to each other without feeling inferior, creating a strong sense of belonging to a community. The difference between rich and poor houses can only be seen if one gets closer to the houses and examines the intricacy of its carvings and size of its spaces. Most people chose to stay close to their kin because of their strong bond. This setting encourages the beautiful culture of gotong-royong (helping each other) which is currently missing in the contemporary urban setting. The high windows in each house with the lattice or carvings allows for 'eyes on the street' (Jacob, 1960) to happen throughout the settlement for safety purposes. These characters also allow for natural ventilation to be experienced in each house and building. Water harvesting are also practiced in the gathering of water from the roof and well of each house and building. Furthermore, the working environments being located below the houses creates vitality in terms of building usage. And for those working at the plantation or as fisherman, the field and jetty were at a walking distance (within $400 \mathrm{~m}$ walking distance). This is similar to the mixed-use development promoted in the contemporary urban design principles, which helps to lower the carbon footprint of both the living and working environments. Linkages between the houses creates a kampung or village. These kampung merge into the central administration, economic and religious area that comprises of the main leader's house (palace)(law) - the main mosque (masjid jamek) (environment) and the main markets (pasar payang and pasar tanjung) and the residents of the kinship of the leader and workers/artisans (people). This vitality is further enhanced at the public open spaces connected to these main central components of the town, which draw various public activities to these areas. Amazingly, all of these important components of the town include wells, which allow free access to water. Linkages between these components are highly legible and pertinent to the locals, enhancing accessibility to all the major components of the town that bind together the community. However, strategically the organic nature of these settings was not legible to outsiders, which helps to enhance security measures in the neighbourhood. Based on this discussion it is obvious that each of the main components within the village make up a larger nucleus of the Malay-Islamic Town. The essence of the Islamic City can be felt with the duplication of these nucleus and the urban design principles applied within it. According to Shojaee, \& Paeezeh (2015), Islamic cities are built based on the Islamic values and principles, but how people responded to them will 
greatly differ in terms of geography and climate, time and accessibility of resources and facilities and this is evidence in Kuala Terengganu. Table 3 summarizes the Urban Design Principles in Malay-Islamic Town from the characteristic of the Malay-Islamic town of Kuala Terengganu.

Table 3. Established list of Urban Design principles in Kuala Terengganu MalayIslamic town.

1) Blue Green City - the buildings are responding to the river/seas or green open space (Laman)

2) Compactness - Distance between living and work. Houses combine with working area and distance to jetty or plantation area are in a walking distance

3) Complete Neighborhood - People can live, work and received basic services within the neighborhood

4) Conviviality - Neighborhoods are social and lively with personal space, family, community and with other cultures

5) Ease of movement - the town is walkable within the $400 \mathrm{~m}$ radius and also very permeable

6) Health and safety - water, air quality and safety/ defense are the fundamental goal

7) Human Scale - cities are built at human scale for the comfort of people
8) Neighborhood character - unique character and values that respond to the local context

9) People first - cities are built with priority of the people and not for cars. And no segregation between rich and poor

10) Public spaces - open spaces for public gathering and link from one to the other

11) Quality of life - Strong neighbourhood: culture of gotong royong

12) Heritage conservation -traditional architecture and values are preserved

13) Sustainable Design -green technology: water harvesting and local resources for the material

14) Efficiency - Energy and resource efficient: maximum use of natural ventilation

15) Transition Design - the growth of the town happen as the need comes, change slowly does not transforms overnight

\section{CONCLUSION}

Kuala Terengganu is generally a worthy example of an early Malay-Islamic Town which portrayed clarity in its urban design principles. Fifteen Urban Design principles (Table 3) were derived based on the comparisons of the urban design principles in Arab-Islamic cities and the Malay-Islamic City of Terengganu. The findings are very important revelations that highlighted the significant and the relevance of our local heritage which already embedded the urban design principles that is currently being discussed and aimed to be achieved by contemporary scholars and Sustainable Development Goals. In conclusion, it is pertinent for the decision makers of future cities to re-examine and relearn from the achievements of earlier local cities and towns that have taken into consideration a great deal about the rule of the place, as guided by the Quran, and social, economic and environmental sustainability in Urban Design. It is highly 
Nurul Syala Abdul Latip \& Nor Zalina Harun, Alias Abdullah, Mansor Ibrahim

Derivation of Urban Design Principles in Malay-Islamic Town of Kuala Terengganu

recommended for the development of future cities to take into consideration on the 15 Urban Design principles that has already been embedded in the MalayIslamic town as stated in Table 3 as a framework to develop future cities in Malaysia towards effort to retain its identity and sense of place and a more sustainable city.

\section{ACKNOWLEDGEMENT}

This research is supported and funded by MOHE - Ministry of Higher Learning under TRGS16-03-0020-20002 and Universiti Sains Islam Malaysia (USIM).

\section{REFERENCES}

Abdullah Zakaria Ghazali. (1984). Terengganu: Dahulu dan Sekarang. Kuala Lumpur: Persatuan Muzium Malaysia.

Al-Quran. Translation by: Sahih International

Besim Hakim (1986). Arab-Islamic Cities, Building and Planning Principles, Routledge, London

Haji Buyong Adil. (1982). Sejarah Terengganu. (pp 78) Kuala Lumpur: DBP.

Khoo Kay Kim. (1974). Kuala Terengganu: International Trading Centre in Malaysia in History. (pp 16). Kuala Lumpur: Persatuan Sejarah Malaysia.

Jacob, J. (1993). Death and Life of American Cities.Random House. New York

Muhammad Hasan al-Aydrus, Penyebaran Islam Di Asia Tenggara, Asyraf Hadramaut Dan Peranannya, (Pent. Ali Yahya, Jakarta: P.T. Lentera Basritama, 1996), 56.

Shojaee, F., Paeezeh, M. (2015). Islamic City and urbanism, an obvious example of sustainable architecture and city. Science Journal (CSJ), 36(6), 1300-1949

Sternberg, E. (2007), Integrated Theory of Urban Design. Journal of American Planning Association. Volume 66. Pg 265-278

Received: January 2020. Accepted: $1^{\text {st }}$ April 2020 